\section{A RECUPERAÇÃO SOCIAL DOS DELINQÜENTES}

\section{Gilda Maciel Corrêa Meyer Russomano}

"Hoje a justiça pronuncia sua sentença sôbre o de. liqüente; mas, por sua vez, depois de um lapso de anos, a sociedade pronuncia sua sentença sôbre a justiça".

\section{CARPENTER}

"O homem é e será sempre o assunto principal dos estudos do homem".

\section{ESMERALDINO BANDEIRA}

O pensamento do homem não é fixo. Suas idéias não são imutáveis como as rochas de granito que atravessam os séculos sem que o tempo consiga alterar-lhes ou modificar-lhes a estrutura. Pelo contrário; variam com o passar dos anos e das gerações, a medida que adquirimos nova compreensão dos fatos e das coisas, e ao influxo descortinador de novos conhecimentos.

Êsse fenômeno pode ser verificado na medicina, na engenharia, na filosofia, em todos os ramos, emfim, da atividade humana.

Os dementes que hoje são encarados e tratados com a compaixão que sempre despertam os enfermos, já foram um dia perseguidos e condenados como criminosos, como se não bastasse a desgraça que lhes acarretava a sua própria e miserável condição.

A técnica operatória da atualidade, há cem anos atrás, não fazia sequer parte dos sonhos dos cirurgióes mais audazes e arrojados.

A conquista do espaço, o encurtamento das distâncias, a aproximação dos continentes, tornados hoje realidade com o advento da era dos aviões, não passavam, até relativamente bem pouco tempo, de mera criação fantástica e inatingível.

No campo filosófico, vemos, constantemente, transformarem-se os conceitos e modernizarem-se as teorias.

O mesmo acontece no Direito.
A ciência jurídica também não permanece estratificada. Ao invés, mais talvez do que nenhuma outra, expõe-se, contìnuamente, à luz de novos sóis e presta-se à influência vivificadora das inovações.

E dentro dela, no campo mais restrito de cada uma de suas divisões, igual processo se verifica.

Idéias sucedem-se a idéias. Pensamentos substituem pensamentos. A evolução é constante e ininterrupta. E' que o homem sente, sempre, irresistível e avassaladora, a necessidade de aperfeiçoar seus modos de encarar a vida, de aniquilar as barreiras impostas ao seu espírito, de construir um sistema social mais justo e equilibrado, de procurar viver, enfim, em um mundo melhor e mais compreensivo.

“A evolução das instituições jurídicas é a conclusão fundamental da moderna Filosofia do Direito. Não existem princípios imutáveis e absolutos, anteriores à experiência ou independentes de suas novas àquisições; todos os ramos do Direito - entre êles o Penal devem considerar-se como funcões evolutivas de sociedades que, incessantemente, evolucionam" ( $\left.{ }^{\mathbf{1}}\right)$.

No campo particular do Direito Criminal, ao analisarmos o seu progressivo desenvolvimento histórico, encontramo-lo dividido por quatro marcos que assinalam os seus quatro grandes períodos, a saber: I - o da vingança privada; II o teológico-político da vinganca divina; III - o humanitário; IV - o científico $\left(^{2}\right)$.

Nos dois primeiros imperavam o arbítrio, a tortura, as execucões sumárias, a crueldade; e o que passava por Justiça nada mais era que uma paródia trágica e ridícula.

Caberia à Itália, pela voz de um de seus filhos, o Marquês de BECCÁRIA, a glória de fazer com que o Direito Penal desse o primeiro passo no sentido de sua humanização. A Escola Clássica aboliu o suplício e as penas bárbaras; fêz cair por terra o arbítrio das autoridades, estatuindo a igualdade entre os indivíduos e estabelecendo uma proporção entre a pena e o delito; fixou aquela, de modo restrito, na figura do delinqüente; introduziu a inovação de entregar à família do criminoso punido, e não ao Estado, o seu cadáver; imprimiu, enfim, à distribuição de Justiça um cunho mais moderado, mais humano, e, por isso mesmo, mais racional.

Anos mais tarde, tocaria ainda à nação italiana a tarefa de confiar ao mundo as idéias de LOMBROSO, tempos depois desenvolvidas e ampliadas pelo gênio de FERRI - o criador da Escola Po-

(1) JOSG INGENIEROS - "Criminologia", pag. 25. 
sitiva - e de GARÓFALO. O Direito Penal entrava no seu período científico. "Nos dias de arbítrio, BECCÃRIA disse ao Homem Conhece a Justiça; e nos dias da Escola Positiva, LOMBROSO disse à Justiça - Conhece o Homem!" - (VAN HAMMEL).

Desde então, muito tem progredido o Direito Penal. Procura-se estudar a personalidade do delinqüente, as influências que sôbre êle pesam, as taras hereditárias que o escravizam e as anomalias físicas, psíquicas e morais que o assinalam, seguindo o rumo apontado por aquela verdade que já se vai tornando axiomática: "Não há crimes, mas criminosos".

Ainda muito, porém, resta por fazer, principalmente no capítulo referente à sanção. Tão importante é a pena em Direito Criminal que já se pensou em tornar o seu estudo ramo autônomo da árvore jurídica, sob a denominação de Penalogia.

Impõe-se, relativamente ao assunto, uma questão preliminar: Tem a sociedade o direito de punir?

Excluindo-se os anarquistas, que negam de modo peremptório aos governos tal direito, a resposta geral a essa interrogação é afirmativa. Quando, porém, se procuram explicar e definir os fundamentos que legitimam o direito de punir, surgem as controvérsias, chocamse as opiniões, cruzam-se as teorias.

Três grandes escolas podemos, então, de logo, distinguir: a absoluta, a relativa e a eclética ou mista.

Para os adeptos da primeira - também chamada subjetiva ou moral - na própria natureza da pena encontra-se o seu fundamento jurídico, traduzido no princípio da justiça absoluta, segundo o qual o vício deve ser castigado e o bem deve ser premiado. "A pena é legítima porque é justa".

Tal teoria é inadmissível, porque, "incompleta e extremada, confunde o crime com o pecado e a justiça moral com a justiça social" $\left({ }^{3}\right)$.

O segundo sistema - relativo, utilitário ou objetivo - busca legitimar a pena pela sua utilidade na manutenção da ordem coletiva. Abandona-se a idéia da justiça como fundamento do direito de punir, para adotar-se a idéia de utilidade como razão do mesmo direito. Aplica-se a pena, não por ser ela justa, mas por ser necessária em função de sua utilidade. Os criminosos são inimigos da sociedade; devem, pois, ser reprimidos, e é a pena que opera essa repressão, por seu efeito intimidante.

Contrabalançando o patente exclusivismo dessa teoria e da que a precedeu, surgiu uma terceira eseola - mista ou eclética - procurando conciliar as duas primeiras. Vê, na lei ética, a legitimidade

(3) COSTA E MACEDO - "Direito Oriminal", pág. 17. da pena, mas limita-a pela utilidade social. Fundidos, os dois princípios solucionam a questão. Isolados, conseguem, apenas, refletir uma imagem incompleta e imperfeita da realidade, porque, no ensinamento de MARCHETTI, "erra quem procura fundamentar a origem do direito de punir sòmente no princípio da defesa, desconhecendo a parte que é devida ao princípio da justiça; erra quem o fundamenta, ùnicamente, neste último princípio, sem restringi-lo nos limites da nessecidade da defesa".

$\hat{E}$ necessário, pois, harmonizar os dois pontos de vista (subjetivo e objetivo), porque nesse "conceito de ecletismo é que se inspira o sistema da tutela jurídica, com o qual coincide o princípio utilitário que deve limitar o princípio da justiça absoluta; tudo que não for tutela jurídica será exorbitante do princípio de utilidade social. A necessidade, que há, de ser o Direito o soberano da humanidade e de que esta soberania se mantenha incólume de qualquer ataque - eis o que legitima o direito de punir.

A violação do Direito desintegra a ordem jurídica; a pena recompóe e reintegra a ordem jurídica violada. Não se podendo permitir que a união social tenha fim, abandonando-se tudo ao capricho individual, é mister que coercitivamente, por via de repressão, se faça respeitar aquela parte da lei moral, cuja observância concorre à conservacão da vida da sociedade; e esta necessidade é a suprema razão do direito de punir, razão que é o ditame do justo, do útil e do bem, e que nos serve de critério e guia".

O fim que se procura alcançar por meio da pena não pode ser mais encerrado na fórmula concisa de HUGO DE GROOT: "A retribuição do mal que se fêz pelo mal que se padece".

Até certo ponto é salutar a expiação em que ela se traduz; mas ainda mais benéfico é o efeito intimidante exercido pela sanção ou mesmo apenás pela sua simples perspectiva nos criminosos potenciais. Pelo temor de sofrê-la, aprende-se a evitá-la.

Não se pode aceitar, atualmente, que seja o sofrimento, como retribuição ao mal cometido, a única função da pena. Antes disso, e sobretudo, além disso, ela deve ser um elemento preventivo do delito e um fator preponderante na recuperação social do delinqüente. "Não pode ser - na palavra autorizada de VAN HAMMEL - o preço pelo qual se compra à sociedade o direito de perturbá-la, mas a sanção das leis que proíbem seja ela perturbada."

Não basta que se afastem do seu convívio os indivíduos perniciosos e nocivos à comunidade. É preciso readaptá-los e educá-los para que voltem, sempre que possível, a êsse mesmo convívio. Não 
é suficiente a punição (sob qualquer de suas formas), sem que a acompanhe o objetivo mais alto da regeneração.

Cumpre aprender a encarar a pena como uma defesa e não como um castigo. Assim, mesmo quando se tratar de indivíduos inassimiláveis, a pena a êles imposta não deve ser considerada como - preço do mal realizado, mas como o remédio de que lança mão - Estado para se defender contra os perigos oriundos de sua falta de adaptação. "À pena-castigo é necessário suceder a pena-defesa e a pena-educação" ( $\left.{ }^{4}\right)$.

Para ser legítima, é indispensável que a pena seja, preliminarmente, útil e justa. Além dêsses, porém, outros característicos devem ainda revesti-la.

Assim, a pena deve ser pessoal, isto é, deve restringir-se à pessoa do criminoso. Foi essa, aliás, como vimos, uma das grandes conquistas da Escola Clássica. Atualmente, já não mais se discute sôbre isso. Entre nós, é expressa e taxativa a letra do Código: "Art. 11 - $\mathrm{O}$ resultado, de que depende a existência do crime, sòmente é imputável a quem lhe deu causa. Considera-se causa a ação ou omissão sem a qual o resultado não teria ocorrido."

Outrora, porém, a infâmia que recaía sôbre o criminoso estendia-se também aos seus parentes. Pagavam vários pelo crime de um só.

É necessário ainda, para a eficácia da sanção, que ela seja individual e aplicada proporcionalmente às condições pessoais de cada ser. Seguindo as idéias de ENRICO FERRI, ousamos com bater o critério da unidade da pena, mesmo quando aplicado a criminosos punidos pelo mesmo delito (roubo, homicídio, a cricastigados da mesma forma (reclusão).

Tal critério, fundamentalmente errado, é “a razão da bancarrota dos atuais sistemas penais" e, na opinião do genial penalista italiano acima citado, "do contínuo aumento do genial penalista italiano, víduos condenados muitas e muitas vêzes, comcidências e dos indicandaloso vaivém do cárcere para a vida livre é para o tribunal. A lei indica cada crime com um número livibunal. A lei indica cada crime com um numero nos artigos do Código; o juiz procura no Código o número do artigo a colar sôbre os ombros do acusado; e o executor da sentença reduz o condenado a um número de matrícula. Pelo que, em todo estabelecimento carcerário, entra uma multidão anônima de condenados à mesma forma de pena, numa estranha mistura de jovens e velhos, sãos e doentes, neuropatas e psico-neuropatas, ociosos e trabalhadores, tranqüilos e turbulentos, deficientes e inteligentes, operários especializados ou
vulgares e indivíduos sem profissão, etc.”.

(4) ENRICO FERRI - "Direito Criminal", pág. 353.
E preciso, pois, dar ao juiz a faculdade de aplicar a pena INDIVIDUALMENTE, não se limitando, para tanto, à análise e à. definição do crime, mas detendo-se, sobretudo, na investigação pormenorizada da personalidade do delinqüente e das suas condições peculiares.

A individualização da pena está necessária e intrìnsecamente ligada à sua indeterminação.

Além de individual, deve também a sentença ser INDETERMINADA.

Se se admite que a função da pena é não sòmente expiar o crime e preveni-lo, como, principalmente, educar aquêle que o cometeu, tem-se de admitir, da mesma forma, a indeterminação da pena, pois não se pode para tão magna tarefa marcar prèviamente um período certo de segregação, da mesma maneira que se não pode precisar o tempo exato da cura de um enfêrmo enviado a estabelecimento hospitalar. É impossível estabelecer, a priori, o prazo necessário para a reforma de um caráter.

A pena deve ser determinada ùnicamente pela regeneração do delinqüiente ou pela sua morte, no caso particular do incorrigível. Durante tanto tempo enquanto um indivíduo se constituir provada ameaça às condições existenciais do homem e da sociedade, deve ser segregado por uma pena que tenha a duração correspondente. Se a ameaça durar, indeterminadamente, que, indeterminadamente, dure a pena." Mas, ao contrário, se cessar aquela antes mesmo do que se poderia prever com um mínimo de êrro, deixemos que sirva de limite à duração da sentença a reabilitação do criminoso. "Não pode atribuir-se ao juiz o dom de adivinhação que lie permita prever a data em que um delinqüente estará corrigido, caso desta reforma seja suscetível; e, se não o é, resulta burlada a sociedade no direito de sua defesa e proteção ao chamar outra vez para o seu seio a mesma pessoa destinada a ferir os seus interêsses e violar as suas leis" (5).

Como objetam alguns, naturalmente, é êsse um terreno propício ao engano, às fraudes, à falsidade. $\mathrm{O}$ delinqüiente, visando tão sòmente à libertação, poderá simular com habilidade ter-se emendado quando, de fato, permanecem intatos e incorrigidos seus vícios e seus estigmas.

Para evitá-lo, é preciso que se confie a observação dos encarcerados a psiquiatras que os submetam aos testes e provas necessários à revelação de seu verdadeiro estado de espírito. Não é encargo que se destine a simples guardas penitenciários. Mais uma vez, é preciso que o Direito recorra à Medicina. E, para tal fim, faz-se

(5) INGENIEROS - Op. cit., pág. 181. 
necessária a criação de verdadeiros órgãos técnicos especializados junto a cada estabelecimento disciplinar. FERRI propóe mesmo a înstalação de um "Conselho de Vigilância", composto pelo Diretor, pelo Médico (antropólogo-criminalista), pelo Professor, pelo $\mathrm{Ca}$ pelão e também por um condenado, escolhido entre os de melhor comportamento. "Fica assim excluída - acrescenta - a possibilidade de injustiças ou favoritismos e são, pelo contrário, garantidos dêsse modo tanto o direito individual do condenado, como o da sociedade, que não receberá, como até agora, todos os dias, a volta de elementos inadaptados e mesmo irredutíveis a uma vida normal."

As hesitações a que poderia conduzir, nesse particular, o desenvolvimento incipiente das ciências antropológicas (em especial dáqueles que aprofundam suas raízes no húmus da alma) e das quais decorreriam eventualmente injustiças contra o direito de liberdade do detento recuperado para a vida coletiva - serão superadas se dosarmos o critério pelo regime mais ou menos liberal dos "livramentos condicionais", que impedem o prolongamento excessivo da reclusão, sem prejuízos à comunidade, porque se permite aos representantes da lei e do Estado acompanhar os primeiros passos do criminoso na arena social a que êle volta. Por outro lado, a concessão do "livramento condicional", de per si, cerca-se de cautelas estudadas prèviamente, da índole das indicações feitas pelo Congresso Penitenciário Internacional de 1.910, reunido em Washington $\left({ }^{6}\right)$.

Uma sábia e científica aplicação dos princípios de individualização e indeterminação da pena só pode consistir no caminho mais seguro para a recuperação dos delinqüentes.

Ligado intrìnsecamente à questão da pena e sua função reabilitadora está o problema penitenciário.

Não é de hoje o combate dirigido por médicos, sociólogos e juristas às penitenciárias. Data de LOMBROSO. A endocrinologia e a psicanálise, sobretudo, criticam-nas acerbamente.

O estado' contemporâneo da organização social e a imperfeição. da ciência, entretanto, não nos permitem dispensá-las. "A penitenciária ainda é necessária, em nossos tempos, como escola de aperfeiçoamento e não como depósito de criminosos que chegam a perder o nome pelo número; como estabelecimento de sociabilização do delinqüente e não como fomentador da loucura e do suicídio, como meio de assistência social onde vão aprender ofício os que ignoram ou se aperfeiçoam os que o sabem" ( 7$)$.

(6) Voto relativo à sentença de duração indeterminada, artigo $4 .{ }^{\circ}$, alinea " $O$ " 1. (7) CARLOS XAVIER P. BARRETO - "O Crime, o Criminoso e a Pena",
São diversos os sistemas penitenciários usados desde BECCÃRIA até nossos dias. Acompanhando a evolução do conhecimento humano, êles surgiram sucessivamente, visando a um aperfeiçoamento cada vez maior. Há abismos de diferença entre as prisões promíscuas e o reformatório de Elmira. Mas ainda não se chegou ao ápice.

O problema é dos mais complexos e em sua solução se vêm empenhando grandes vultos do Direito Criminal.

Não nos deteremos a analisá-lo detalhadamente. Pensamos, porém, que, para que possam preencher seu fim natural e elevado, isto é, a recuperação para a sociedade de indivíduos dela afastados por seus crimes, devem as penitenciárias oferecer aos condenados, a par de condições higiênicas satisfatórias, um programa de vida que inclua: trabalho, instrução, educação moral e religiosa e, até mesmo, distrações.

Não se julgue com isso que se pretenda para os delinqüentes uma vida cômoda e fácil, isenta de sacrifícios, como se o mal que praticaram, ao invés de castigo, merecesse recompensa. $\mathrm{Na}$ verdade, para muitos dêles, uma existência organizada nessas bases seria, ao menos do ponto de vista meramente material, abstraindo-se, por completo, o sofrimento em que se traduz a privação da liberdade, experiência nova e agradável. Mas não confundamos. Tal experiência lhes é oferecida não como prêmio ao delito cometido, mas com a finalidade superior e humanitária de os educar e de os habituar a uma vida tanto quanto possível sadia e normal.

Já INGENIEROS agudamente observara: "Dois critérios falsos têm desviado a opinião dos legisladores. Os sentimentalistas fazem de todo o delinqüente um "anjo caído" por culpa da sociedade; os pessimistas o consideram um "predestinado" fatalmente à criminalidade, independente dos fatôres sociais que influem sôbre sua conduta. Para os primeiros, todo delinqüente é suscetível de reforma e isto leva a mitigar no possível a crueza das penas; seu resultado é a ineficácia das leis penais vigentes, contra a delinqüência profissional, e a ampliação do benefício da irresponsabilidade penal em favor de certos criminosos perigosíssimos. Para os segundos, todo delinqüente é irresponsável, sendo, portanto, ineficaz todo esfôrço dirigido para sua reeducação moral, para sua readaptação social; resulta disso a severidade penal e penitenciária contra delinqüentes acidentais, que volvem à sociedade depois de perder nos cárceres tô-. das as boas tendências, adquirindo, por sua vez, os hábitos e a moral própria dos delinqüentes profissionais. $\mathrm{O}$ cárcere é para êles uma escola do crime."

Não batalhamos, porém, por nenhum dêsses critérios. Não chegamos ao extremo de responsabilizar a sociedade pelos crimes. 
de todos os delinqüentes, embora, na verdade, grande parcela de culpa lhe possa ser atribuída. Mas também não nos colocamos no terreno oposto, entre aquêles que negam, peremptòriamente, aos criminosos qualquer possibilidade de regeneração, considerando-os definitiva e perpètuamente marcados por seus estigmas. Preferimos ficar no têrmo médio, sempre mais perfeito, embora também sempre mais difícil de atingir: o delinqüente não é nem anjo, nem demônio; é um homem como os outros, que, levado por sua vontade ou por seus impulsos ou por suas taras, atentou contra a ordem social, contra os direitos alheios, contra a paz da sociedade.

Entre as condições higiênicas que reputamos indispensáveis em uma penitenciária, incluem-se: celas limpas e individuais; alimentação simples, mas sadia; exercícios físicos ao ar livre e a solução do problema sexual por um dos métodos atualmente adotados, como, por exemplo, o das visitas periódicas feitas aos presidiários por suas espôsas ou companheiras.

Proporcionar aos encarcerados uma existência hígida é preservar-lhes a saúde e conservá-los aptos para o trabalho, além de ser em si mesma uma tarefa de solidariedade humana.

A base de tôda a vida carcerária deve ser o trabalho. Sempre que possível, os presos devem exercer sua própria profissão. Deve-se ensinar-lhes um ofício qualquer, de acôrdo com suas preferências, quando o desconheçam.

Várias finalidades se colimarão, ao mesmo tempo: a ocupação útil e proveitosa de grande parte do dia dos encarcerados; o aprendizado, para muitos dentre êles, de um labor honesto; a formação de um pecúlio para o condenado e sua família, pois que, de acôrdo com a lei, o trabalho penitenciário deve ser remunerado. Dispóe expressamente a respeito o nosso Código Penal, em seu artigo 29, parágrafo 1.0: - "O sentenciado fica sujeito a trabalho que deve ser remunerado e a isolamento durante o repouso noturno."

O trabalho penitenciário, embora remunerado, não é atingido pelo Direito Social, porque, "sendo o acôrdo de vontades elemento característico do contrato, é evidente que os serviços dos detentos não constituem prestação de um contrato individual de trabalho". ( $\left.{ }^{8}\right)$

Não invalida essa conclusão o fato de poder o detento escolher seu labor ,desde que encerre caráter educativo.

Quanto à remuneração - é ela empregada, em parte, para prover às necessidades da família do detento e para formar-lhe um pecúlio; mas o é, em parte, também, para reparar o dano resultante do delito e proporcionar a execução da multa.

(8) A. F. CESARINO JÚNIOR - "Direito Social Brasileiro", 2 o volume
Por outro lado, apesar da liberdade de escolha do serviço, năo tem o prêso liberdade quanto à sua prestação, que o Estado lhe pode, autorizadamente, exigir.

Apesar dêsses argumentos, para nós irrespondíveis, vários autores propugnam pela aplicação dos princípios gerais do Direito Social ao trabalho penitenciário.

Na América do Norte, em 1911, por ocasião de um gravíssimo acidente ocorrido nas minas do Alabama, onde morreram 123 prisioneiros em conseqüência de uma xeplosão, nasceu a idéia de estender aos trabalhadores penitenciários os benefícios da legislação especial contra acidentes em serviço e moléstias profissionais.

O Brasil de hoje consagrou o princípio, ex-vi do artigo $9 .^{\circ}$, parágrafo $2 .^{\circ}$, da Lei de Acidentes do Trabalho.

O Código Penal nada diz a respeito. Como pondera JORGE SEVERIANO, entretanto, a Constituição de 1937, embora ficasse na generalidade, já preceituava, sem cogitar da natureza do serviço: “A legislação do trabalho observará, além de outros, os seguintes preceitos: - a instituição de seguros de velhice, de vida, de invalidez e para os casos de acidente de trabalho" (art. 137, alínea "M"). A nossa atual Carta Magna nada encerra que elida o dispositivo citado da Lei de Acidentes de Trabalho; mas só exige a instituição do seguro pelo empregador, isto é, nas relações comuns entre patrão e operário, originadas de um contrato ${ }^{9}$ )

Para que seja produtivo o trabalho penitenciário e possa preencher seus fins - a um tempo econômicos e moralizadores - é preciso que seja realizado em ambiente higiênico e adequado, em condições, tanto quanto possível, normais. A exigência é imprescindível; sem ela, o serviço a ser prestado seria visto, temido e odiado pelo detento como apenas mais uma provação a suportar.

Além dos ensinamentos particulares de que venha, ocasionalmente, a necessitar na execução de seu trabalho, deve o penitenciário receber uma instrução geral, ainda que básica e rudimentar. A aquisição de uma certa cultura poderá facilitar-lhe um meio de vida honesto quando voltar a viver em sociedade. $\hat{E}$ reclamado, pois, ao menos, um professor em cada presídio, que tenha ao seu alcance uma biblioteca adequada ao nível médio geral dos sentenciados. É o princípio científico que GUERRA JUNQUEIRO transformou em poesía pura, quando pediu qeu as salas das prisões se transformassem em salas para escolas.

Os detentos devem receber, do mesmo modo, educação moral e ensino religioso.

\footnotetext{
(9) "Código Penal dos Estados Unidos do Brasil", 2.ำ volume, pág. 111.
} 
É imprescindível que se lhes possam incutir os princípios e ensinamento morais que desconhecem ou que desprezaram, por meio de leituras ou palestras simples e apropriadas.

Como complemento, também se lhes deve facultar o ensino religioso, pois segundo CUCHE, "a experiência provou qeu a religião é o melhor veículo da moral".

Não se objete que a imposição de instrução religiosa importa em violar a liberdade de consciência do condenado. Não esqueçamos que, ao infringir a lei e perturbar a ordem pública, êle provou não ter sabido formar essa consciência, cabendo assim ao Estado o direito e, sobretudo, o dever de procurar suprir essa lacuna. Além disso, é preciso que se não confunda ensino religioso com assistência religiosa; o primeiro deve ser ministrado coativamente apenas aos que nấo possuam nenhum credo; aos que, porém, professarem já uma religião devem ser proporcionados, por meio de visitas periódicas de seus ministros, o amparo e o confôrto que dela possam derivar. Não se imporá, neste caso, ao detento esta ou aquela religião; apenas lhe será facilitada a prática daquela que êle seguir.

$O$ prêso faz jus a um pouco de distração, de divertimento, de alegria; tal objetivo pode ser conseguido permitindo-se-lhe a leitura de revistas, livros e jornais; e possibilitando-lhe, uma ver que outra, sessões de música ou de cinema.

Não se julguem demasiados e improfícuos tantos cuidados para com indivíduos que já provaram sua periculosidade; justamente para prevenir novas ameaças, para anular-lhes as tendências más e desenvolver as boas que porventura possuam, todos os esforços devem ser tentados. Cumpre procurar, acima de tudo, reconciliar o criminoso com a sociedade que êle ofendeu, mas que, assim mesmo, ou melhor, por isso mesmo, não o abandonou.

O conjunto de requisitos que acabamos de enunciar e de comentar, ràpidamente, deve existir em tôdas as prisões do território nacional. Não é suficiente a simples construção de prédios grandiosos. O que importa é aquilo que se procura dentro dêles realizar. Não basta, também, que possamos exibir, ocasionalmente, a distintos visitantes nacionais ou estrangeiros, dois ou três estabelecimentos, mais ou menos satisfatórios, ou mesmo perfeitos. $\tilde{\mathrm{E}}$ urgente que em tôdas as penitenciárias do Brasil, grandes e pequenas, imponentes e humildes, a preocupação básica e fundamental seja exclusivamente a reeducação dos delinqüentes.

Chegamos a dizer que a tarefa da sociedade nấo cessa quando se alcançou, finalmente, a regeneração do criminoso. Ela deve continuar mesmo depois de transpostas as paredes do cárcere.

Deve ser, porisso, encarado de frente o grande problema da colocação dos ex-senienciados.
Olhados com desconfiança, aliás compreensível, por todos ou pela maioria, terão êles fatalmente dificuldade de obter um alojamento decente e uma colocação honesta e digna. Farão uma, duas, três tentativas; repelidos sempre, terminarão por cansar-se. Impelidos pela necessidade, pela revolta, pelo desânimo e pela amargura, voltarão à antiga vida. Tôda a obra já realizada no sentido de recuperá-los socialmente estará então perdida. O que se levou anos inteiros para conseguir, pode ser perdido em poucos meses.

- Se a maioria dos particulares não deseja aceitar em suas casas, em suas indústrias, em seus estabelecimentos, em suas emprêsas os egressos da penitenciária, julgando-os ainda pelo seu passado e duvidando de sua reabilitação, caberá ao Estado intervir para solucionar tão angustiante problema. Tocar-lhe-á a tarefa de dar emprêgo aos ex-presidiários em suas próprias indústrias e em suas próprias obras; e parece-nos, neste caso, que o órgão indicado para agir em seu nome será o Ministério Público.

Não se objete que existem já associacões ou organizacôes beneficentes, tendo por finalidade única a proteçã́o dos delinqüentes libertos. Tais organizações, por mais poderosas que sejam, não se podem igualar ao Estado na amplitude da ação ou nos recursos disponíveis.

Com a colocação dos liberados, entretanto, não finda a responsabilidade do govêrno; é conveniente que se exerça sôbre êles, sôbre sua vida privada e, principalmente, sôbre suas atividades profissionais, intensa vigilância -tal qual costuma acontecer, nos Estados Unidos da América do Norte, em casos de livramento condicional. A sociedade deve ampará-los e ajudá-los, mas deve também, por sua vez, ser protegida contra suas possíveis reincidencias. Tal vigilância, porém, não deve ser acintosa, nem mesmo notória, porque, "além de reviver constantemente aos olhos do indivíduo o seu passado delituoso - cousa que, em muitos casos, êle desejaria esquecer por completo -, agrava a suspeita e a repulsa com que é visto pelo público o egresso do cárcere. Semelhantes imposições dificultam a reforma pessoal do criminoso e sua assimilação social" ${ }^{10}$ ).

A maioria dos autores condena uma organização oficial na obra de ajuda aos ex-condenados, julgando preferível, no caso, por mais eficaz, a iniciativa privada. Discordamos. Além de possuir o Estado meios e recursos de que não dispõem as entidades particulares, por mais fortes e eficientes que sejam, conta com o auxílio e a cooperação de um sem-número de funcionários públicos e com o prestígio de sua autoridade. Naturalmente, não poderá êle obrigar ninguém a alojar ou empregar ex-penitenciários; mas também não

(10) ESMERATDINo BANDEIRA - "Política Criminad", pág. 162. 
poderá coagir êstes a receberem benefícios e proteção, caso não os desejem. A caridade não é coisa que se exija, mas támbém não coisa que se imponha.

Sôbre o relevante problema da recuperação social dos delinqüentes ainda não se disse, felizmente, a última palavra. Como já frisámos, a evolução dos fatos e dos pensamentos é constante e contínua.

No campo do Direito Penal, principalmente, com referência à pena, é considerável o aparecimento incessante de novas idéias, de novos conceitos e de novas teorias, visando à substituição de idéias, conceitos e teorias que se começam a julgar insuficientes ou errôneos.

Em tôda a evolução humana e social, aliás, "um momento se depara em que as velhas idéias se encontram com as idéias novas num ponto de interseção de suas diferentes diretrizes. As primeiras, já esgotadas em seus ensinamentos, não podem mais disciplinar os fatos novos; as segundas fragmentadas em doutrinas parciais, não têm ainda achado a fórmula geral que os abranja e discipline".

É preciso, então, conciliá-las, integralizá-las, sintetizá-las. E êsse o instante decisivo das reformas sociais, quando é conveniente que se conjuguem os esforços e as inteligências e se irmanem as aspirações.

Estamos vivendo um dêsses momentos.

A hora presente é uma hora de renovações. Saibamos reconhecê-lo e aplicar seus frutos às questões sociais que ainda necessitam de solução ou de aperfeiçoamento nas fórmulas encontradas pela ciência e pelo espírito.

Entre estas avulta e se agiganta a recuperação social dos delinqüentes e sua readaptação à vida em sociedade.

As falhas neste assunto importarão em novos crimes e em novas reincidências. Os esforços e os trabalhos conjugados de todos os componentes do grupo social tornam-se necessários, para essa obra de paz, de cooperação, de solidariedade.

Urge que cada cidadão, individualmente, compreenda a parte de responsabilidade que lhe toca, pois o que está em jôgo, em última análise, é o bem da sociedade; e é necessário que esta, consciente de seus deveres e de suas obrigaçóes, auxilie e ampare as iniciativas individuais, tudo envidando para trazer novamente ao seu seio aquêles que ela mesma justamente afastara por seu crimes, e estendendo, de modo generoso, a thão ao homem que caiu, mas que, com um esfôrço sincero e corajoso, procura erguer-se novamente.

\section{O N C L U S O E S}

1 - A pena deve ser individual porque se se admite que ela deve ser considerada não como a retribuição do mal pelo mal, mas. como fator decisivo na regeneração do delinqüente, é imprescindível que antes de a determinar se procure conhecer o indivíduo a quem se pretende aplicá-la. "Uma pena indevida e desigual humilha, deforma e corrompe ainda mais o criminoso".

2 - A pena deve ser indeterminada e condicionada sòmente à emenda do encarcerado.

Se esta ficar devidamente provada, conceda-se a liberdade e não se insista em uma segregação que pode transformar-se de elemento reeducativo em fator de revolta, de amargura e de retôrno aos hábitos e vícios que se pretendem corrigir. Mas também se, contràriamente, o indivíduo continua incorrigido, inadaptado e mesmo perigoso desde que o estudo das ciências antropológicas, a organização da máquina judiciária e o gráu de perfetibilidade humana o permitam verificar com relativa precisão - impõe-se o prolongamento de sua detenção.

3 - O fundamento da vida penitenciária deve ser o trabalho trabalho adequado às qualidades pessoais de cada um e remunerado proporcionalmente ao seu valor. Mas, da mesma forma, é preciso que êle seja realizado dentro de condiçốes higiênicas e saudáveis, bem como que o acompanhem, intensas e efetivas, a instrução e a educação moral-religiosa.

4 - Recomenda-se, por parte dos governos, a criação de órgãos oficiais especializados incumbidos de colocar aos libertos condicional ou totalmente - de acôrdo com suas aptidões e preferências - nas emprêsas exploradas pelo Estado e, mesmo, por particulares, sempre que êstes queiram aceitá-los.

Competirá, ainda, aos citados órgãos a vigilância continuada eficiente dos delinqüentes liberados para observação de seu compor tamento e de suas atitudes no desempenho das funções profissionais que lhes foram asseguradas.

Não se negligenciará, assim, a defesa do grupo social, cuja tranqüilidade cumpre, antes de tudo, assegurar; mas não se negará aos egressos do cárcere uma oportunidade de entrada ou de retôrno vida pacífica, digna e honrada dos cidadãos normais.

Pelotas, em 27 de julho de 1950. 


\section{RELATORIO E PARECER}

Relator: RUBENS SANT'ANNA

A Dra. Gilda Maciel Corrêa Mayer Russomano, da nobre Faculdade de Direito de Pelotas, enviou, a êste Congresso Jurídico, um tese sob o título de "A recuperação social dos delinqüientes", que nos coube a honra de relatar perante a $4 .^{\mathrm{a}}$ Comissão.

Antes de apreciarmos o trabalho em tela, e sôbre êle emitirmos nosso modesto juízo, entendemos de dever ressaltar o emitirmo gesto de sua apresentação a êste Congresso ressaltar o significativo ainda pertence ao corpo disce entesso, de vez que sua autora cunstância essa que revola estudante, na pesquisa ra o louvável interêsse e ardor de jovem studante, na pesquisa da ciência jurídica.

Inicia, a autora, seu trabalho, fazendo uma explicação, ou mequistas do explanação introdutória em tôrno da evolução das contécnica, da filosofiato humano, no terreno das ciências positivas, da enica, da filosofia e, por igual, do direito.

Apreciando o evolver das disciplinas jurídicas, destaca o Direito rido per analisando seu desenvolvimento dentro do esquema sugeprivada; II, o teológico-preendendendo quatro períodos: I, o da vingança privada; II, o teológico-político da vingança divina; III, o humani-
tário; IV, o científico.

Dentro dêsse esquema, examina a autora, em rápido bosquejo, o direito criminal primitivo, a contribuição monumental da Escola Clássica e, por último, da Escola Positiva, representada por Lombroso, Garófalo e Ferri, período êste que considera científico.

Partindo daí, a autora acolhendo o axioma de que "não há crimes mas criminosos", endereça seu estudo para o problema da sanção penal, argüindo, sôbre o assunto, uma preliminar: "tem a sociedade o direito de punir?"

Admitindo e sustentando que essa interrogação deve ser respon dida afirmativamente, menciona as controvérsias que, no terreno da Sôbre o tema, passo quanto à fundamentação do direito de punir. escolas funa, passa, então, com brilho, a autora a expor as três admitir a insuficiênis: a absoluta, a relativa e a mista. Depois de admitir a insuficiência das duas primeiras, salienta o equilíbrio de acêrto da última.

Feita essa exposição, a tese passa a focalizar o problema da pena em si, tomando por ponto de partida a oposição à fórmula de Hugo de Groot: "a retribuição do mal que se fêz pelo mal que se

Admitindo, até certo ponto, a expiação na pena, a autora entende mais benéfico seu efeito intimidativo. Demais, repudia seja o sofri- mento, como retribuição ao mal cometido, a única função da pena. Melhor, entende deva ser ela um elemento preventivo do delito.

Passa a explanar sôbre a função educadora e readaptadora da pena, sustentando, com apoio em Ferri, que a pena é uma defesa e não um castigo. Sustenta a utilidade, a justiça e pessoalidade da pena, invocando, sôbre êste último aspecto, o artigo onze do vigente Código Penal Brasileiro.

Nessa ordem de idéias, a autora, seguindo as rotas de Ferri, sustenta a individualização da pena, combatendo o critério de unidade da mesma. Como conseqüência dessa posição, afirma, textualmente, que "a individualização da pena está necessária e intrìnsecamente ligada à sua indeterminação".

A seguir, desenvolve o tema de que "além de individual, deve também a sentença ser indeterminada". Apóia, a autora, êste seu ponto de vista, no argumento de que a função da pena não é sòmente a de expiar o crime e prevení-lo, mas, principalmente, a de educar o criminoso. Entende, daí, ser impossível estabelecer, a priori, o devido prazo para a reforma do caráter do criminoso. Aceita a determinação da pena, apenas pela regeração do delinqüente, ou pela morte no caso do incorrigível.

Admitindo a possibilidade de fraude, no presídio, por parte do presidiário, sustenta que a observação dos mesmos deve ser confiada a psiquiatras e a órgãos técnicos especializados. Lembra, com apoio em Ferri, a instalação de um Conselho de Vigilância, integrado pelo Diretor, um médico, um professor, o capelão e um condenado de bom comportamento.

Após sustentar o sistema de individualização e de indeterminação da pena, a autora passa a encarar o problema penitenciário. Defendendo a necessidade de existência das mesmas, sustenta que devem elas "oferecer, aos condenados, a par de condições higiênicas satisfatórias, um programa de vida que inclua: trabalho, instrução, educação moral e religiosa e, até mesmo, distrações".

Sustentando, numa posição de equilíbrio, que "o delinqüente não é nem anjo nem demônio", a autora disserta sôbre as condições higiênicas que uma penitenciária deve ter, tais como celas limpas e individuais, exercícios físicos e solucionamento do problema sexual. Amparada no Código vigente, defende o trabalho carcerário remunerado, focalizando aspectos do mesmo. Defende, do mesmo modo, devam ser ministradas, aos detentos, educaçãoo cultural, moral e ensino religioso aos que não possuam nenhum credo, bem como assistência religiosa de acôrdo com as conviç̧ões pessoais. Examina o problema da colocação dos ex-sentenciados, cuja solução entende caber ao Estado, apontando como órgão indicado o Ministério Público.

8 - R. D. - 2.0 Vol. 
Dissertando, por último, em considerações finais, sôbre o pro blema da recuperação social dos delinqüentes, a autora apresenta as conclusões da tese, que são as seguintes:

$1 .^{\mathrm{a}}$ - A pena deve ser individual porque se se admite que ela deve ser considerada não como uma retribuição do mal pelo mal mas como fator decisivo na regeneração do delinqüente, é imprescindível que antes de a determinar se procure conhecer o indivíduo a quem se pretende aplicá-la.

$2 .^{a}-$ A pena deve ser indeterminada e condicionada sòmente $a$ emenda do encarcerado. Se esta ficar devidamente provada, conceda-se a liberdade e não se insista em uma segregação que pode transformar-se de elemento reeducativo em fator de revolta, de amargura e de retôrno aos hábitos e vícios que se pretendem corrigir. Mas também se, contràriamente, o indivíduo continua incorrigido, inadaptado e mesmo perigoso - desde que o estudo das ciências antropológicas, a organização da máquina judiciária e o gráu de perfetibilidade humana o permitam verificar com relativa precisão impõe-se o prolongamento de sua detenção.

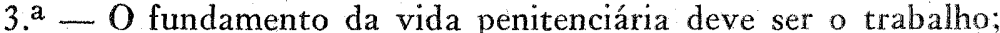
trabalho adequado às qualidades pessoais de cada um e remunerado proporcionalmente ao seu valor. Mas, da mesma forma, é preciso que êle seja realizado dentro de condições higiênicas e saudáveis bem como que o acompanhem, intensas e efetivas, a instrução e a educação moral-religiosa.

$4 .^{a}$ - Recomenda-se, por parte dos governos, a criação de órgãos oficiais especializados incumbidos de colocar aos libertos condicional ou totalmente - de acôrdo com suas aptidões e preferências - nas emprêsas exploradas pelo Estado e, mesmo, por particulares, sempre que êstes queiram aceitá-los. Competirá, ainda, aos citados órgãos a vigilância continuada e eficiente dos delinqüentes liberados para observação de seu comportamento e de suas atitudes no desempenho das funções profissionais que lhes foram asseguradas. Não se negligenciará, assim, a defesa do grupo social, cuja tranqüilidade cumpre, antes de tudo, assegurar; mas não se negará aos egressos do cárcere uma oportunidade de entrada ou retôrno à vida pacífica, digna e honrada dos cidadãos normais.

\section{PARECER}

A presente tese, fora de dúvida, a nosso entender, focaliza aspectos relevantes do problema da aplicação e do cumprimento da pena, sendo, portanto, de interêsse evidente para um Congresso Jurídico.

Está, o trabalho que acabamos de sucintamente relatar, vasado em têrmos repassados de sensibilidade, reveladores de um espírito jovem que sente os problemas focados.
Em sua orientação jurídico-penal, evidencia-se uma formação cultural abeberada, de perto, nas fontes dos mestres da Escola Positiva da Ciência Criminal, sem negar, no tema, o que seria mesmo insustentável, a transcendental contribuição da Escola Clássica.

Atendo-nos, em nosso parecer, às conclusões da ilustre autora - de vez que já proclamamos o mérito da forma de desenvolvimento do assunto, - examinemos a primeira delas.

Entendemos, com a autora, que a pena deve ser indidualizada, isto é, adatada ao criminoso.

É o sistema seguido por nossa lei penal, em seu artigo 42, corresponde a uma exigência da moderna ciência criminal, que visa não apenas o castigo do delinqüente, mas, precìpuamente, sua readatação social. Nesse sentido, deve a pena objetivar, como sustenta Roberto Lyra, "a eliminação da causa do crime".

Assim, concordamos plenamente com a primeira conclusão da autora.

Em sua segunda conclusão, a autora defende a indeterminação absoluta da pena. Como frisamos no relatório, afirma que a "individualização da pena está necessária e intrìnsecamente ligado à sua indeterminação.

A essa conclusão, foi a autora conduzida seguindo a lição de mestres da Escola Positiva, como Ingenieros e Ferri.

Não nos parece que seja a melhor doutrina, por isso não concordamos com a conclusão.

De fato, como acentua Costa e Silva, "predominam em nosso tempo, na legislação dos povos civilizados, as penas relativamente determinadas."

$O$ nosso vigente Código Penal, em seu artigo 42, ao consagra individualização da pena, adotou, com acêrto, na cominação, a indeterminação relativa da mesma. Ê o critério justo, em que "a lei fixa ou alterna a qualidade e estabelece o máximo e o mínimo, em cujos limites o juiz faz a concretização."

A pena, para atingir os fins visados pela defesa social, deve ser individualizada, mas o seu critério de fixação, por isso que é um instituto jurídico-penal, não pode ser retirado ao juiz e confiado a uma junta penitenciária.

Não é admissível, hoje, que recuemos ao passado, tornando o juiz um mecânico aplicador da lei. De outro lado, é inaceitável, por igual, que ao juiz seja subtraída a faculdade de encontrar, com integral conhecimento do delito e do delinqüente, a pena adequada.

$\mathrm{O}$ aspecto puramente teórico da indeterminação absoluta da pena, reforçado pelo argumento de que é quase impossível ao juiz pexatidão, pode causar impressão.

Entretanto, em sua realidade, tal sistema fatalmente acarretaria as mais desastradas conseqüências. 
Por último, entendemos, como objeção fundamental, que a adoção daquele sistema viria ferir, profundamente, a natureza jurídica do instituto da pena, com a retirada, ao juiz, do seu arbítrio de dosar a sanção.

Com agudeza, sustenta Roberto Lyra, em seus Comentários ao Código Penal (art. 42), que "o arbítrio judicial constituirá o melhor instrumento de comunhão entre o direito penal e a ciência penal. Incumbe ao juiz, no exercício dêsse arbítrio, transfundir nos textos o sangue sempre renovado da sociologia, da antropologia e da psicologia criminais."

A terceira conclusão, dando como fundamento da vida penitenciária o trabalho adequado ao detento, a nosso entender, merece aprovação, por constituir norma consagrada pela moderna política correcional.

A quarta conclusão, recomendando a criação, por parte do Estado, de órgãos especializados, incumbidos de conseguir empregos para os liberados condicionais e para egressos definitivos das prisões, encerra uma proposição de elevado alcance social, enquadrável nos salutares princípios da política preventiva do delito.

Este é o nosso parecer.

15 de agôsto de 1950.

\section{Rubens Sant'Anna}

Relator

\section{DEBATES EM PLENÁRIO}

O Sr. PRESIDENTE - Darcy Azambuja - (substituindo ocasionalmente o sr. Salgado Martins) - Temos sôbre a Mesa a tese da Doutora Gilda Maciel Corrêa Mayer Russomano: "A Recuperação Social dos Delinqüentes".

Ocorrendo não estar presente o relator da tese, consultou-se a autora da tese; concorda, ela mesma, em relatar sua tese, e ousaria pedir, que fôsse breve, devido ao adiantado da hora.

Tem, portanto, a palavra a autora da tese.

A SRA. GILDA CORREA MAYER RUSSOMANO: - Ilustre sr. Presidente, srs. Congressistas. Alterando a ordem habitual seguida vou ler, primeiro, as conclusóes de minha tese, justamente devido à premência da hora.

As conclusões que foram aceitas pela douta Comissão foram as seguintes: (lendo)

"1 - A pena deve ser individualizada, isto é, adaptada ao criminoso.
E' o sistema seguido por nossa lei penal, em seu artigo 42 , e corresponde a uma exigência da moderna ciência criminal, que visa não apenas o castigo do delinqüente, mas, precipuamente, sua readaptacão social. Nesse sentido, deve a pena objetivar, como sustenta Roberto Lyra, "a eliminação da causa do crime".

2 - O trabalho adequado ao detento é fundamental na vida penitenciária, norma consagrada pela moderna política correcional.

3 - E' recomendável, por parte do Estado, a criação de órgãos especializados, incumbidos de conseguir empregos para os liberados condicionais e para os egressos definitivos das prisões, proposição de elevado alcance social, enquadrável nos salutares princípios da política preventiva do delito".

Essas três conclusões foram aceitas pelo sr. Relator.

Lerei, agora, a que mereceu parecer contrário:

"A autora da tese defende a indeterminação absoluta da pena:

Afirma que a "individualização da pena está necessária e intrìnsecamente ligada à sua indeterminação", seguindo a lição dos mestres da Escola Positiva, como Ferri e Ingenieros.

Não nos parece que seja a melhor doutrina.

De fato, como acentua Costa e Silva, "predominam em nosso tempo, na legislação dos povos civilizados, as penas relativamente determinadas".

O nosso vigente Código Penal, em seu artigo 42, ao consagrar a individualização da pena, adotou, com acêrto, na cominação, a indeterminação relativa da mesma. E' o critério justo, em que "a lei fixa ou alterna a qualidade e estabelece o máximo e o mínimo, em cujos limites o juiz faz a concretização".

A pena, para atingir os fins visados pela defesa social, deve ser individualizada, mas o seu critério de fixação, por isso que é um instituto jurídico-penal, não pode ser retirado ao juiz e confiado a uma junta penitenciária.

Não é admissível, hoje, que recuemos ao passado, tornando o juiz um mecânico aplicador da lei.

De outro lado, é inaceitável, por igual, que ao juiz seja subtraída a faculdade de encontrar, com integral conhecimento do delito e do delinqüente, a pena adequada.

$\mathrm{O}$ aspecto puramente teórico $\mathrm{da}$ indeterminação absoluta da pena, reforçado pelo argumento de que é quase impossível ao juiz sentenciar com acêrto e rigorosa exatidão, pode causar impressão.

Entretanto, em sua realidade, tal sistema fatalmente acarretaria as mais desastradas conseqüências.

Entendemos, como objeção fundamental, que a adoção daquele sistema viria ferir, profundamente, a natureza jurídica do instituto da pena, com a retirada, ao juiz, do seu arbítrio de dosar a sanção. 
Com agudeza, sustenta Roberto Lyra, em seus Comentários ao Codigo Penal, (artigo 42), que - "o arbítrio judicial constituirá o melhor instrumento de comunhão entre o direito penal e a ciência textos incumbe ao juiz, no exercício dêsse arbítrio, transfundir nos textos o sangue sempre renovado da sociologia, da antropologia e da
psicologia criminais".

Vou me limitar apenas a justificar o meu ponto de vista, - ligeiramente.

Penso que a pena deve ser indeterminada, pelo seguinte:

A individualização da pena está necessária e intrìnsecamente ligada à sua indeterminação.

A sentença deve ser - indeterminada.

Se se admite que a função é não sómente expiar o crime preve ni-lo, como, principalmente, educar aquêle admitir, da mesma forma, tem-se de pode para tão pode para tão magna tarefa marcar prèviamente um período certo de segregação, da mesma maneira que se não pode precisar o tempo

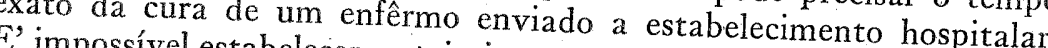
E impossível estabelecer, a priori, o prazo necessário para a reforma de
um caráter.

A pena deve ser determinada ùnicamente pela regeneracão do delinqüente ou pela sua morte, no caso particular do incorrigível "Durante tanto tempo enquanto um indivíduo se constituir provada ameaça à condições existenciais do homem e da sociedade, deve ser seameaça durar indena que tenha a duração correspondente. Se a ameaça durar, indeterminadamente, que indeterminadamente, a pena". Mas, ao contrário se cesar aqueterminadamente, dure poderia prever com um mínimo se cessar aquela antes mesmo do que à durac̃̃o buir-se ao da sentença a reabilitação do criminoso. "Não pode atribuir-se ao juiz o dom de adivinhação que lhe permita prever a data costará corrigido, caso desta reforma seja sus cetivel, e, se não o é, resulta burlada a sociedade no direito defesa e proteção ao chamar outra vez para o seu seo destinada a ferir os seus interêse vez para o seu seio a mesma pessoa gia", Ingenieros, pá ín

Como objetam algur

ao engano, às fraudes àns, naturalmente, é êsse um terreno propício te a sua libertac̃̃o quando, de fabilidade ter-se emendado quando, de fato, permanecem intatos e incorrigidos seus vícios e seus

Para evitá-lo, é preciso que se confie a observação dos encarcetestes e provas necesác revelação de seu verdadeiro estado de espírito. se destine a simples guardas penito de espírito. Não é encargo que que o Direito recorra à Medicina. E, pará tal fim, faz-se necessária a criação de verdadeiros órgãos técnicos especializados junto a cada estabelecimento disciplinar.

FERRI propõe mesmo a instalação de um "Conselho de Viilância", composto pelo. Diretor, pelo Médico (antropólogo-criminalista), pelo Professor, pelo Capelão e também por um condenado, escolhido entre os de melhor comportamento.

"Fica assim excluída - acrescenta - a possibilidade de injusticas ou favoritismos e são, pelo contrário, garantidos dêsse modo tanto o direito individual do condenado, como o da sociedade, que não receberá, como até agora, todos os dias, a volta de elementos inadaptados e mesmo irredutíveis a uma vida normal".

As hesitações a que poderia conduzir, nesse particular, o desenwolvimento incipiente das ciências antropológicas (em especial daqueles que aprofundam suas raízes no húmus da alma) e das quais decorreriam eventualmente injusticas contra o direito de liberdade do detento recuperado para a vida coletiva serão superadas se dosarmos o critério pelo regime mais ou menos liberal dos "livramentos condicionais", que impedem o prolongamento excessivo da reclusão, sem prejuízos à comunidade, porque se permite aos representantes $d a$ lei e do Estado acompanhar os primeiros passos do criminoso na arena social a que êle volta. Por outro lado, a concessão do "livramento condicional", de per si, cerca-se de cautelas estudadas prèviamente, da índole das indicaçốes feitas pelo Congresso Penitenciário Internacional de 1910, reunido em Washington. (Voto relativo à sentenca de duração indeterminada, artigo 4.0 alínea " $\mathrm{C}$ ".

Uma sábia e científica aplicação dos princípios de individualização e indeterminação da pena só pode consistir no caminho mais seguro para a recuperação dos delinqüentes.

O SR. PRESIDENTE - Está em discussão. dente.

O SR. CELSO CEZAR PAPALEO - Peço a palavra sr. Pre-

O SR. PRESIDENTE - Tem a palavra o Frof. Celso Cezar Papaléo.

O SR. CELSO CEZAR PAPALEO - Sr. Presidente e srs. Congressistas. Procurarei sintetizar o meu ponto de vista, que é, preliminarmente, de integral apoio às conclusões da ilustre autora da tese.

Infelizmente, não temos oportunidade, aqui, de poder comentar, como já fizemos ao discutir também na sessão da manhã na Comissão, o relatório apresentado pelo ilustre relator do trabalho. Foi de fato assunto bastante discutido na sessão da manhã. e chegámos a uma situação tal que entendemos acertado, de acôrdo mesmo com o regimento, trazer ao plenário a discussão do assunto, porisso que opiniôes divergentes se verificaram de manhã, em sessão da Comissão 
e chegámos, finalmente, a uma situação de verdadeiro impasse, erm seu verdadeiro sentido, por isso que não conseguimos dar uma solução ao assunto de forma perfeitamente clara.

Se de um lado se colocaram aquêles que, com seus argumentos defendiam o ponto de vista da autora, de outro lado, não menos acertados e não menos eficientes em seus argumentos, estavam seus opositores. Eu me coloquei do lado daqueles que o apoiaram e continuo mantendo agora êste decidido a io por que apoiaram e continuo compatível com a minha maneira de pensar sôbre o assunto e também porque esta minha maneira de pensar, além dos arsunto e tampossa trazer, encontra razões de sobra além dos argumentos que desenvolvida pela autora do trabalho.

Trago, srs., um depoimento de médico, trago, portanto, a um Congresso Jurídico o depoimento de um homem que tem contato talvez mais íntimo que o jurista, com uma série de aspectos da conduta humana no seu sentido mais lato, mas com a realidade humana do ponto de vista que especificamente interessa ao estudo do crime através do criminoso. No estudo do crime através do criminoso, buscando talvez inspiração naquela obra que começa com Lombroso e se desenvolve através do palmilhar da ciência do estudo do homem no setor do crime, eu trouxe para a minha formação cultural a convicção que faz com que afirme que devemos legitimar a indeterminação da pena, porque só assim atenderemos, de maneira verdadeiramente humana, à própria finalidade da pena.

Entendo que não podemos sustentar opinião diversa, levando em conta o gráu de adiantamento atingido pela ciência penal.

Creio que as nossas medidas neste sentido deverão ter alguma correspondência quanto ao apoio que possa demandar a ciência. Não poderemos coonestar os elementos científicos que possam tecer a nossa opinião com uma opinião divergente quanto a isso, que deveremos aceitar a indeterminação da pena.

Creio - e insisto na expressão - creio que haja uma divergência, uma incoerência de posições entre aceitar a validade do depoimento científico e, ao mesmo tempo, defender a determinação da pena.

Insisto na honestidade do meu depoimento e na firme decisão de dar o meu apoio a tôdas as conclusões da ilustre autora da magnífica tese, que, com sua inteligência, vem colaborar para da mabrilho dêste Congresso.

Naturalmente, na minha argumentação, ver-se-á por certo, ena minha maneira de pensar, o espírito objetivo do médico, que abstrai locubrações jurídicas as maiores, mas que en médico, que abstrai mesmo, na formação de sua própria consciência profissional, os elementos que fazem com que êle não possa assumir outra atitude e é por isso mesmo que, reputo honestíssima a minha opinião. $\mathrm{E}$ não vai nisso o atestado de uma determinante pura e simplesmente afetiva, por isso que esta minha opinião é uma opinião consciente.

E' possível que o meu ponto de vista não seja aceito, mas quero exatamente sustentá-lo porque entendo que não posso ter outro, de vez que a própria feição da minha formação cultural faz com que siga exatamente êste rumo, com que dê êste passo afirmativo no sentido de levar o meu apoio, que é o apoio do médico, do médico com uma relativa experiência sôbre estas questões, à ilustre autora da tese e que estou inteiramente solidário com suas conclusões.

Hoje pela manhã o assunto foi fartamente discutido. Argumentos jurídicos vários e brilhantes foram trazidos à consideração da Comissão, e nós os ouvimos cheios de interêsse e ávidos de aprender, de discutir, de criticar. Mas apesar do brilho de todos êstes argumentos jurídicos, o médico se manteve irredutível na sua posição e é com satisfação, com honesta satisfação, que vos confesso que, a despeito de todos êstes argumentos, que pude pesar no valor que lhes dou através da minha capacidade de juiz, não pude modificar a minha opinião. Por isso que ouvi, entre outras cousas, que ao juiz não cabia outra atitude senão a de recusar a indeterminação da pena porque tinha experiência de um regime no qual a pena não é indeterminada e esta experiência da pena determinada fêz com que êle, observando o decurso do comportamento, o desenvolvimento da conduta do criminoso, durante a vigência da pena determinada, lhe trouxesse elementos para achar que sua conduta não seria aquela no sentido de o reintegrar na sociedade, pela modificação de sua atitude, e até mesmo, de sua mentalidade se a pena fôsse indeterminada. Por isso que indeterminação da pena equivaleria exatamente a uma insegurança indefinida dêste homem, quanto a isso de algum dia vir a recuperar a liberdade.

Creio que o argumento fôsse sofístico, pois que partia de premissa certa, porém deficientemente valorizada. Por isso de maneira alguma poderemos antepor a um determinado argumento, totalmente hipotético, um outro baseado exclusivamente na realidade, mas que valorizamos para que o possamos apresentar em suas decorrências hipotéticas. Eu vi, além disso, a firme atitude daqueles que por outras razões entendiam dever a pena ser determinada, valorizando, como disse, o meu modo de entender e a minha capacidade apreciativa, não encontrei razões, repito, que me demovessem de atitude em que me mantenho - e que agora vou repetir - de integral solidariedade, de perfeita concordância com a evidente conclusão da brilhante tese da autora.

O SR. PRESIDENTE - Continua em discussão. 
O SR. PLAUTO D'AZEVEDO - Peço a palavra, sr. Presidente.

O SR. PRESIDENTE - Tem a palavra o ilustre Congressista.

O SR. PLAUTO D'AZEVEDO - Exmo. sr. Presidente. Srs. Congressistas. Minhas senhoras. Meus senhores.

Hoje, pela manhã, na $4 .^{\text {a }}$ Comissão, de que faço parte, tive ocasião de ouvir, atentamente, o trabalho da digna doutora de Pelotas. Tive ocasião de admirar as idéias novas contidas em seu excelente trabalho. D. Gilda figura com destaque nesta equipe cultural que Pelotas nos enviou, e bem merece a nossa profunda admiração pela sua inteligência, pelo seu estudo, pela sua cultura. As idéias do seu trabalho encontram o apoio no que há de mais moderno em ciência penitenciária.

Encontramos a sua orientação naquele programa magnífico que Ingenieros traçou em 1907, a preocupação da etiologia criminal depois da clínica criminal e, finalmente, da terapêutica. Começa preocupada com a individualização da pena, e eu pergunto quem poderá contestar a necessidade de aplicar-se a pena a cada caso, a cada homem, como Lombroso nos ensinou. Pois bem, é a primeira conclusẫo a que chegou a brilhante autora, a necessidade da individualização da pena. Depois chegou à conclusão da sentença indeterminada e D. Gilda, que está com o apoio do grande mestre Jiménez Asúa, naquele seu livro magnífico que se ocupa exclusivamente da sentença indeterminada, porque, senhores, sou contra a dosimetria da pena do Código Penal de 1940. Quando o indivíduo - diz Asúa - não demonstra mais periculosidade - e a periculosidade foi apurada por um gabinete de biotipologia criminal - êle não precisa mais permanecer na prisão, porque a prisão, neste momento, só é prejudicial a êle, à família e à sociedade, porquanto não demonstra mais periculosidade. Entretanto pode outro estar numa prisão 30 anos e ainda ser perigoso ao meio social. Portanto, êle não deve voltar como dizia Asúa - porque vem perturbar a paz jurídica, vem perturbar a nossa tranqüilidade.

Eis o fundamento principal para que a sentença indeterminada seja adotada, como está sendo já em países europeus e países americanos.

E foi por isso, meus senhores, que votei, de consciência, a favor da tese da distinta colega de Pelotas, e espero que êste plenário saiba bem compreender-lhe o esforç̧o, aprovando seu brilhante trabalho. (Palmas).

O SR. PRESIDENTE - Continua em discussão. Não havendo quem queira fazer uso da palavra, vou encerrar a discussão. Passa-se à̀ votação. As conclusões da tese são as seguintes:

\section{(LE AS CONCLUSÓES DA TESE)}

O SR. CELSO CEZAR PAPALEO - Peço a palavra pela ordem, senhor Presidente.

O SR. PRESIDENTE - Tem a palavra o nobre Congressista.

O SR. CELSO CEZAR PAPALÉO - Senhor Presidente. Eu unia esclarecer que a votação foi no sentido de se aprovar ou requeria esclarecer que a votaça foi ceitacão do relatório. Foi essa a provar a tese, implicando isso na aceitação do relatón. votação que se fếz. Votou-se pela tese ou pelo relatório. De maneirg que, exatamente correspondendo ao que se fêz na Comissão, neira que, exatamente dentro das possibilidades de suas atribuipeço a V. Excia. estabeleça, dentro das possibilidades de suas atribuições, êste critério de aprovação ou de consultar a Casa no sentido de se aprovar a tese, que implica, naturalmente, em rejeitar o parecer, ou no sentido de aceitar o parecer, que é a recíproca da situação anterior.

O SR. PRESIDENTE - Mas, V. Excia. poderia prestar mais pequeno esclarecimento. Apenas houve divergência quanto à segunda conclusão?

O SR. CELSO CEZAR PAPALEO - O parecer opinava pela aprovação de tôdas as conclusões, menos a segunda. Aqueles que aprovarem a tese, evidentemente aprovarão todas as conclusões.

O SR. PRESIDENTE - Vou, então, destacar. Vou submeter à votação do plenário, primeiro as conclusões sôbre as quais não houve discrepâncias $\mathrm{e}$, depois, porei em destaque a outra vọtação.

De modo que vou submeter à votação do plenário, as conclusões de $n^{\circ} \mathrm{s} .1,3$ e 4 . Os senhores Congressistas que estão de acôrdo queiram ficar sentados. (Pausa) Aprovadas.

Agora, passarei à votação do destaque. Os senhores Congressistas que o aprovam, queiram ficar sentados. (Pausa) Aprovado.

Está $\mathrm{em}$ votação esta conclusão.

Os srs. Congressistas que estejam de acôrdo, queiram conservar-se sentados. (Pausa)

Foi aprovada a conclusão contra três votos não justificados. (Palmas).

Devido ao adiantado da hora, declaro encerrada a sessão.

Convido a todos os senhores Congressistas para logo, às 20 e 30 assistirem à sessão solene de encerramento.

Luvanta-se a sessão. 